\title{
Electroconvulsive Seizure Alters the Expression and Daily Oscillation of Circadian Genes in the Rat Frontal Cortex
}

\author{
Se Hyun Kim ${ }^{1 *}$, Hong Geun Park ${ }^{2 \star}$, Seong Hoon Jeong ${ }^{3}$, \\ Ung Gu Kang ${ }^{4}$, Yong Min $\mathrm{Ahn}^{4}$, and Yong Sik Kim ${ }^{1 凶}$ \\ ${ }^{1}$ Department of Neuropsychiatry, Dongguk University International Hospital, Dongguk University Medical School, Goyang, Republic of Korea \\ 2Biomedical Research Institute, Seoul National University Hospital, Seoul, Republic of Korea \\ ${ }^{3}$ Department of Psychiatry, Eulji University School of Medicine, Eulji University Hospital, Daejeon, Republic of Korea \\ ${ }^{4}$ Department of Psychiatry, Seoul National University College of Medicine, Seoul, Republic of Korea
}

Objective Electroconvulsive therapy (ECT) is the most effective treatment for mood disorders. Accumulating evidence has suggested the important role of circadian genes in mood disorders. However, the effects of ECT on circadian genes have not been systemically investigated. Methods We examined the expression and daily oscillation of major circadian genes in the rat frontal cortex after electroconvulsive seizure (ECS).

Results Firstly, mRNA and protein level were investigated at $24 \mathrm{hr}$ after single ECS (E1X) and repeated ECS treatements for 10 days (E10X), which showed more remarkable changes after E10X than E1X. mRNA expression of Ror $\alpha$, Bmal1, Clock, Per1, and Cry1 was decreased, while Rev-erbo expression was increased at $24 \mathrm{hr}$ after E10X compared to sham. The proteins showed similar pattern of changes. Next, the effects on oscillation and rhythm properties (mesor, amplitude, and acrophase) were examined, which also showed more prominent changes after E10X than E1X. After E10X, mesor of Ror $\alpha$, Bmall, and Cry1 was reduced, and that of Rev-erb $\alpha$ was increased. Five genes, Rev-erb $\alpha$, Bmal1, Per1, Per2, and Cry2, showed earlier acrophase after E10X.

Conclusion The findings suggest that repeated ECS induces reduced expression and phase advance of major circadian genes in the in vivo rat frontal cortex.

Psychiatry Investig 2018;15(7):717-726

Key Words Electroconvulsive therapy, Circadian rhythm, Clock genes, Cortex.

\section{INTRODUCTION}

The association between circadian rhythm and mood regulation has been established and disturbances in circadian clocks are suggested to contribute to the development of mood disorders. ${ }^{1-3}$ The polymorphisms in the circadian genes, such as CLOCK, NPAS2, ARNTL1, NR1D1, PER3, RORB, and CSNK1, have been reported to be associated with mood disorders. ${ }^{4-6}$ The drugs used to treat mood disorders affect the circadian

Received: December 5, 2017 Revised: January 10, 2018

Accepted: January 18, 2018

$\triangle$ Correspondence: Yong Sik Kim, MD, PhD

Department of Neuropsychiatry, Dongguk University International Hospital, Dongguk University Medical School, 27 Dongguk-ro, Ilsandong-gu, Goyang 10326, Republic of Korea

Tel: +82-31-961-7239, Fax: +82-31-961-7236, E-mail: kys@snu.ac.kr

*These authors contributed equally to this work.

(a) This is an Open Access article distributed under the terms of the Creative Commons Attribution Non-Commercial License (https://creativecommons.org/licenses/bync/4.0) which permits unrestricted non-commercial use, distribution, and reproduction in any medium, provided the original work is properly cited. rhythms and circadian genes. ${ }^{7-11}$ The therapeutic modalities affecting the circadian clock have been applied to the treatment of mood disorders, such as light exposure and sleep-wake schedules shifting. ${ }^{11-14}$

In mammals, circadian rhythms driven by the central pacemaker located in the suprachiasmatic nucleus (SCN) determine endogenous periodicity throughout the body. ${ }^{15}$ Although the important role of circadian gene system in mood regulation has been suggested, there is little evidence to indicate the role of SCN in the pathogenesis of mood disorders. The extrahypothalamic brain regions including frontal cortex, cerebellum, and hippocampus have been reported to contain a circadian oscillator and to express all core clock genes. ${ }^{16-18}$ The association between mood disorders and disrupted clock gene expression has been implicated in extra-SCN brain areas showing rhythmicity, such as medial prefrontal cortex, hippocampus, and amygdala. ${ }^{19-21}$

The circadian clock is maintained and reset through a tran- 
scriptional feedback loop of core circadian genes. ${ }^{22}$ Bmall and Clock dimerize and activate the transcription of Per and Cry; in turn, Per and Cry suppress their own expression through direct interaction with Bmal1/Clock dimers. In another feedback loop, Ror and Rev-erb, members of a subfamily of orphan nuclear receptors, directly regulate the expression of Bmall and Clock through the RORE motif, and Bmal1/Clock dimers reversely activate their expression. ${ }^{15,22}$ Post-translational modifications also play an important role in regulation of the circadian clock system. ${ }^{23}$

The electroconvulsive therapy (ECT) has been widely used to treat psychiatric disorders including mood disorders, which could correct the circadian and homeostatic abnormalities present in mood disorders. ${ }^{24}$ It has been reported that single electroconvulsive seizure (ECS) treatment shows the enhanced Per 1 mRNA expression ${ }^{25}$ but repeated ECS treatment reduced it in the hippocampus. ${ }^{26} \mathrm{ECS}$ affects the expression of immediate early genes (IEGs) such as c-fos and early growth response protein1 (Egr1) in the hippocampus and frontal cortex, ${ }^{27-30}$ which induce changes in circadian gene expression, ${ }^{31,32}$ and modulates the activity of signaling transduction pathways, such as the protein kinase $\mathrm{C}$ (PKC), extracellular signal-regulated kinase (ERK) and glycogen synthase kinase-3ß (GSK$3 \beta)^{33-35}$ involved in post-translation modifications of circadian proteins. ${ }^{23}$

ECT is one of the major therapeutic modalities for the treatment of mood disorders, and the important role of circadian gene system in various brain regions in the pathogenesis and treatment of mood disorders has been increasingly understood. However, the investigations of the effects of ECT on circadian genes in the brain including extra-SCN regions are limited. Frontal cortex is one of the main regions involved in the regulation of mood-related behaviors, ${ }^{36,37}$ and the clock genes are expressed in all six layers of frontal cortex. ${ }^{17}$ In this study, we examined the gene expression of core circadian clock components in the rat frontal cortex after single and repeated ECS treatments.

\section{METHODS}

\section{Animals}

Animals were treated in accordance with the National Institute of Health's Guide for the Care and Use of Laboratory Animals, and formal approval to conduct this experiment was obtained from the Animal Subjects Review Board of Dongguk University Hospital. Male Sprague-Dawley rats (150-200 g) were housed for 1 week before the experiments and maintained under a strict 12-hr light/12-hr dark cycle (lights on 08:00hr), with food and water available ad libitum.

\section{Electroconvulsive seizure treatment}

ECS was applied in the rats using a previously validated technique. ${ }^{28,30}$ ECS was administered via ear-clip electrodes (Ugo Basile ECT Unit-57800-001, Ugo Basile, Italy. Frequency 100 pulses/s, pulse width $0.5 \mathrm{~ms}$, shock duration $0.5 \mathrm{~s}$, current 55 $\mathrm{mA})$. ECS-induced seizure was validated by the observation of general convulsion consisting of tonic and clonic phase and the time measurement of duration of convulsion (more than 30 s). Sham-treated control animals were handled in the same fashion as the ECS treatment group, but no electric current was delivered. Rats in the sham group underwent sham treatment for 10 days. Rats in the single-ECS treatment group (E1X) underwent sham treatment for 9 days and were then administered a single ECS treatment on day 10 , whereas rats in the repeated-ECS treatment group (E10X) were treated with ECS for 10 days. All treatments were administered once a day at the same time (12:00-13:00). Male Sprague-Dawley rats with 6 weeks of age were started to undergo ECS or sham treatment as described above, and, at 8 weeks of age after ECS or sham treatments for 10 days, rats were decapitated at $24 \mathrm{hr}$ after the last ECS treatment to determine the expression level at $24 \mathrm{hr}$. To determine the daily oscillation of circadian genes, rats were decapitated at $4,8,12,16,20$, and $24 \mathrm{hr}$ after the last treatment for the ZT8, ZT12, ZT16, ZT20, ZT0, and ZT4 samples, respectively, where ZT indicates the zeitgeber time. Decapitations in the dark cycle (ZT12-ZT0) were performed under a dim red light to prevent rats from additional light stimuli. The frontal cortex was used for further analyses.

\section{Immunoblot analysis}

Immunoblot analyses were performed as previously described. ${ }^{28}$ Antibodies against Bmall (kindly gifted by Dr. Kyung Jin Kim, Seoul National University), Rev-Erba (Cell Signaling Technology, Beverly, MA, USA), Rora, Clock, Per1, Per2 (Santa Cruz Biotechnology, Santa Cruz, CA, USA), and $\beta$-actin (Sigma-Aldrich, St. Louis, MO, USA) were used at dilutions of 1:1000-1:5000. Blots were incubated with primary antibody overnight at $4^{\circ} \mathrm{C}$. The membranes were subsequently incubated with HRP-conjugated secondary antibody (Zymed Laboratories, San Francisco, CA, USA), and the signals were detected using an enhanced chemiluminescence system (Pierce, Rockford, IL, USA). Immunoblot signals were quantified with the TINA program, version $2.10 \mathrm{~g}$ (Raytest, Straubenhardt, Germany). At least four independent experiments were performed.

\section{Quantitative real-time PCR}

Whole RNA was extracted from the frontal cortex using TRI reagent (Molecular Research Center, Cincinnati, OH, USA) and subsequently reverse-transcribed to cDNA using the $\mathrm{Su}$ - 
perscript II RT system (Invitrogen, Carlsbad, CA, USA). Quantitative real-time PCR was performed using an ABI PRISM 7500 instrument (Applied Biosystems, Foster City, CA, USA) with SYBR Green Real-time PCR master mix (Toyobo, Osa$\mathrm{ka}$, Japan) as previously described. ${ }^{28}$ Relative amounts of all mRNAs were calculated by the comparative Ct method (Applied Biosystems) using the $2^{-\Delta \mathrm{Ct}}$ equation. $\Delta \mathrm{Ct}$ was the difference between the $\mathrm{Ct}$ values derived from the target gene and the $\beta$-actin control, and $\Delta \Delta \mathrm{Ct}$ was calculated by the formula $\Delta \mathrm{Ct}=\Delta \mathrm{Ct}-\Delta \mathrm{Ct}$ of the control group (sham or sham of CT8). The primer sequences for quantitative real-time PCR are summarized in Table 1.

\section{Statistical analysis}

Circadian gene expression levels in mRNA and protein at $24 \mathrm{hr}$ after ECS were analyzed using one-way analysis of variance (ANOVA), followed by Tukey's post hoc test. Relative expression of circadian genes was analyzed using mixed-effect model repeated measure (MMRM) analysis, with six serial assessments over $24 \mathrm{hr}$ (sampling times: ZT8, ZT12, ZT16, ZT20, ZT0, and ZT4) and two groups: sham vs. E1X, sham vs. E10X, and E1X vs. E10X. To test the effects of drugs or other stimuli on the expression of the genes showing circadian rhythms, it was reported to be reliable to apply the single cosinor method by fitting a $24 \mathrm{hr}$ cosine curve to 6 values, $4 \mathrm{hrs}$ apart. ${ }^{38}$ The circadian rhythm of three variables was calculated using the single cosinor method to calculate the mesor (middle value of the fitted cosine representing a rhythm-adjusted mean), amplitude (half the difference between the maximum and minimum of the fitted cosine function), and acrophase (time of peak value in the fitted cosine function, expressed as the lag in hours and minutes from midnight) and standard error (SE) of their dispersion. ${ }^{39,40}$ The six time-normalized means were also analyzed for a time effect by one-way ANOVA for the variables of circadian genes. The rhythm properties (mesor, amplitude, and acrophase) of each variable were compared between the groups by one-way ANOVA. All tests were per- formed using SPSS 19.0 for Windows (IBM Corp., Armonk, NY, USA). p-values $<0.05$ were deemed statistically significant.

\section{RESULTS}

\section{mRNA level of circadian genes in the rat frontal cortex at $24 \mathrm{hr}$ after ECS treatment}

The mRNA level of circadian genes at $24 \mathrm{hr}$ after single (E1X) or repeated (E10X) ECS treatment were examined. Compared with sham treatment, ECS treatment resulted in expression changes of Rev-erbo, Ror , Bmal1, Per1, Cry1, and Cry2, whereas it showed no effect on the expression of Clock and Per2 (Figure 1). Rev-erbo expression was significantly changed $(\mathrm{F}=24.12, \mathrm{p}=0.01)$ which was increased by E10X ( $\mathrm{p}=$ 0.01 ) but not by E1X. The expression levels of Ror $\alpha$, Cry1, and Cry2 were significantly changed $(\mathrm{F}=3.59, \mathrm{p}=0.03 ; \mathrm{F}=10.47, \mathrm{p}=$ $0.02 ; \mathrm{F}=4.77, \mathrm{p}=0.03$, respectively) which was significantly decreased by $\operatorname{E10X}(\mathrm{p}=0.02, \mathrm{p}=0.03, \mathrm{p}=0.02$, respectively) but not by E1X. Bmal1 and Per1 were also significantly affected by ECS treatments $(\mathrm{F}=27.61, \mathrm{p}<0.01 ; \mathrm{F}=5.94, \mathrm{p}=0.03) \mathrm{de}-$ creased by both E1X and E10X (Bmal1 p=0.01, p=0.02; Per1 $\mathrm{p}=0.03, \mathrm{p}=0.02$ ) compared with sham.

\section{Protein level of circadian genes at $24 \mathrm{hr}$ after ECS treatment in the rat frontal cortex}

E10X induced changes in protein levels in circadian genes, but E1X did not show any significant changes compared with sham. Rev-erb $\alpha$ was increased by $\operatorname{E} 10 X(\mathrm{~F}=3.60, \mathrm{p}=0.03)$, whereas Rora $(\mathrm{F}=3.55, \mathrm{p}=0.03)$, Bmal1 $(\mathrm{F}=11.7, \mathrm{p}=0.02)$, Clock $(\mathrm{F}=10.84, \mathrm{p}=0.02)$, and Per1 $(\mathrm{F}=8.58, \mathrm{p}=0.02)$ were decreased significantly compared with sham (Figure 2). However, the protein level of Cryl was not changed by ECS treatment, and that of Cry2 showed an increase in $\operatorname{E10X}(\mathrm{F}=5.44, \mathrm{p}=0.03)$, whereas its mRNA level decreased (Figure 1).

Table 1. Primers for quantitative real-time PCR

\begin{tabular}{llll}
\hline \multicolumn{1}{c}{ Gene } & GeneBank assession & \multicolumn{1}{c}{ Forward } & Reverse \\
\hline Rev-erb $\alpha$ & NM_145775 & ACAGCTGACACCACCCAGATC & CATGGGCATAGGTGAAGATTTCT \\
Ror $\alpha$ & NM_001106834 & CCCGATGTCTTCAAATCCTTAGG & TCAGTCAGATGCATAGAACACAAACTC \\
Bmal1 & NM_024362 & GCAATCTGAGCTGCCTCGTT & CCCGTATTTCCCCGTTCACT \\
Clock & NM_021856 & GGCCAGAGTTCATCGTTTGT & CTCCTCAACGCCAAGTTCTC \\
Per1 & NM_001034125 & ACACCCAGAAGGAAGAGCAA & GCGAGAACGCTTTGCTTTAG \\
Per2 & NM_031678 & GAGAGAGGAACAGGGCTTCC & TTGACACGCTTGGACTTCAG \\
Cry1 & NM_198750 & CAGTTGGGAAGAAGGGATGA & AGGACAGCCACATCCAACTC \\
Cry2 & NM_133405 & GTCCTGCAGTGCTTTCTTCC & CAGGTATCGCCGGATGTAGT \\
$\beta$ - actin & NM_031144 & CCTCTGAACCCTAAGGCCAA & AGCCTGGATGGCTACGTACA \\
\hline
\end{tabular}




\section{Daily pattern of circadian gene expression in the frontal cortex}

We investigated the effect of ECS on the daily oscillations of circadian gene expression. The effects of ECS on the daily expression of circadian genes were examined in the frontal cortex at 4, 8, 12, 18, 20, and $24 \mathrm{~h}$ after ECS treatments.

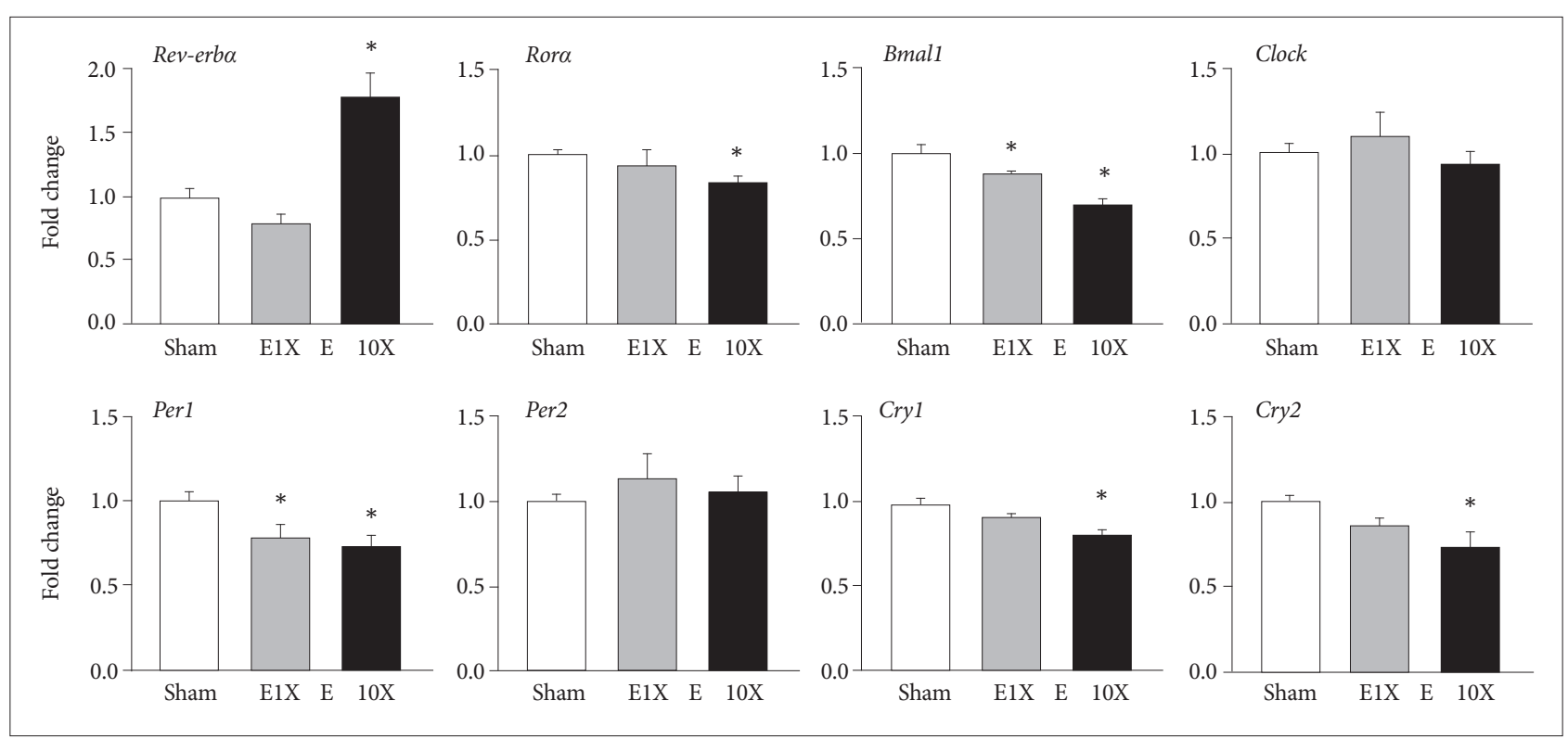

Figure 1. Changes in mRNA levels of circadian genes at $24 \mathrm{hr}$ after ECS treatment. Changes in mRNA expression levels were examined by quantitative real-time PCR analysis at $24 \mathrm{hr}$ after the last ECS treatment. Fold changes in each gene compared with the sham control were normalized to $\beta$-actin expression and represent means \pm SE $(\mathrm{N}=7-9)$. *statistically significant difference in each value compared with the sham control $(p<0.05)$.

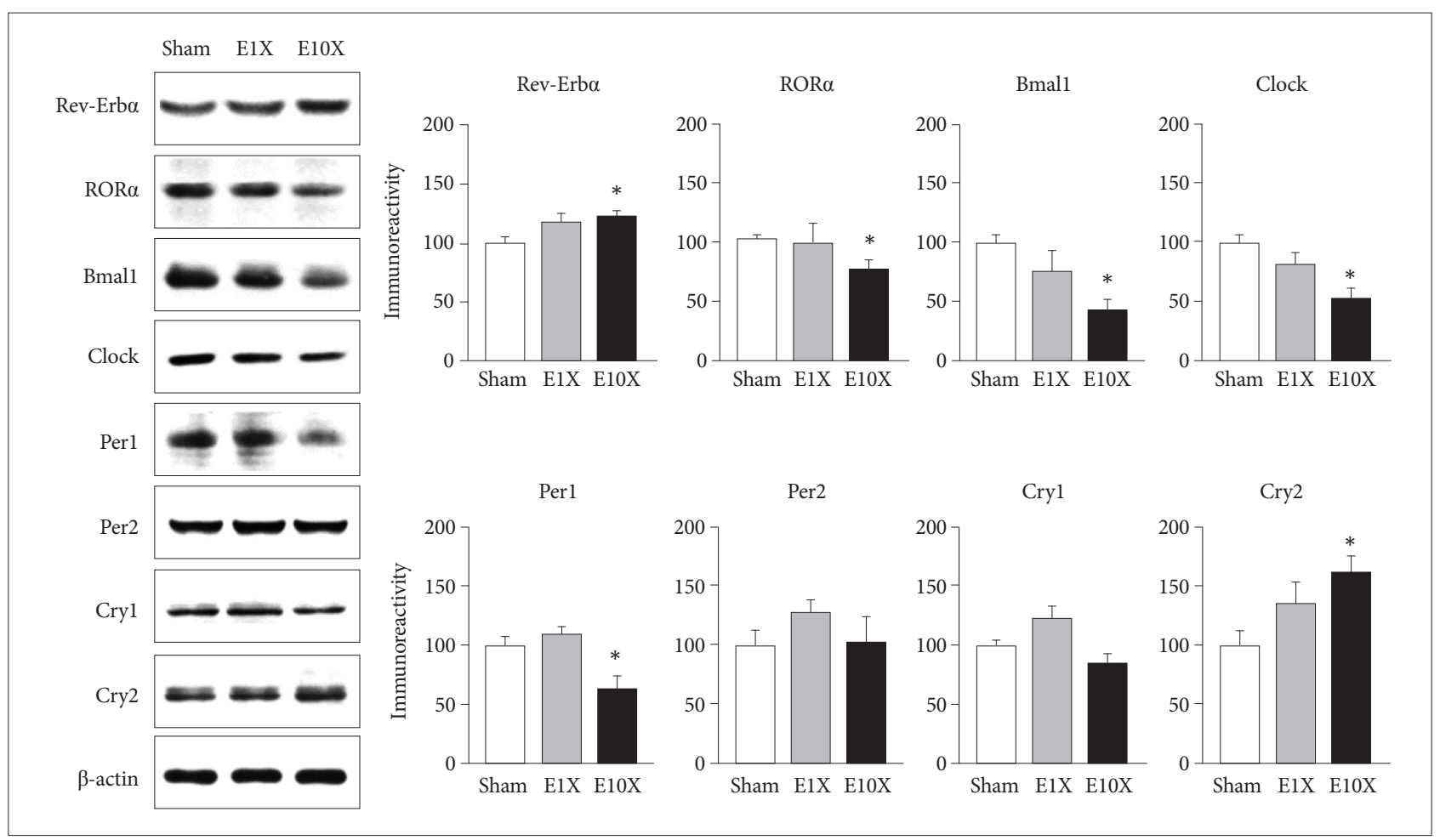

Figure 2. Changes in protein levels of circadian genes at $24 \mathrm{hr}$ after ECS treatment. Representative immunoblots and relative optical densities (ODs) of circadian proteins at $24 \mathrm{~h}$ after the last ECS treatment. The ODs of each gene are normalized to the OD of $\beta$-actin, and relative ODs are shown as percentages versus the ODs of a sham control. Data represent means $\pm \mathrm{SE}(\mathrm{N}=5-7)$. *statistically significant difference in each value compared with the sham control $(p<0.05)$. 


\section{Rev-erba}

Rev-erb $\alpha$ expression showed a statistically significant daily rhythm in sham, E1X, and E10X (Table 2). E1X lowered Reverb $\alpha$ expression $(\mathrm{F}=6.49, \mathrm{p}=0.03)$, and a group $\times$ time interaction was observed $(\mathrm{F}=3.73, \mathrm{p}=0.04)$ compared with sham. E10X increased Rev-erb $\alpha$ expression $(\mathrm{F}=19.10, \mathrm{p}=0.02)$, and a group $\times$ time interaction was found $(\mathrm{F}=7.01, \mathrm{p}<0.01)$ compared with sham. The mesor was significantly affected $(\mathrm{F}=17.58, \mathrm{p}=0.02)$ that decreased in E1X $(\mathrm{p}=0.03)$ and increased in E10X ( $\mathrm{p}=$ $0.01)$ compared with sham. The acrophase was observed approximately $3 \mathrm{hr} 40 \mathrm{~min}$ earlier in E10X $(\mathrm{p}=0.02)$ than in sham (Figure 3, Table 2).

\section{Rora}

Ror $\alpha$ expression showed a statistically significant daily rhythm in sham, E1X, and E10X (Table 2). Rorc expression level was not changed by E1X, while a group $\times$ time interaction $(\mathrm{F}=2.52, \mathrm{p}=0.04)$ compared with sham was observed. E10X lowered Ror $\alpha$ expression ( $\mathrm{F}=21.25, \mathrm{p}=0.02)$, and no group $\times$ time interaction was observed. The mesor was decreased in E10X ( $F=7.64, p=0.02)$, but the acrophase and amplitude showed no changes after ECS treatment (Figure 3, Table 2).

\section{Bmal1}

Bmal1 expression showed a statistically significant daily rhythm in sham, E1X, and E10X (Table 2). Bmal1 expression was decreased by both E1X $(\mathrm{F}=44.69, \mathrm{p}<0.01)$ and E10X $(\mathrm{F}=$ $18.95, \mathrm{p}<0.01)$, and group $\times$ time interactions were noted in $\mathrm{E} 1 \mathrm{X}(\mathrm{F}=2.49, \mathrm{p}=0.03)$ and in $\mathrm{E} 10 \mathrm{X}(\mathrm{F}=3.61, \mathrm{p}=0.02)$ compared with sham. The mesor was significantly affected $(\mathrm{F}=12.27, \mathrm{p}=$ 0.02 ) that decreased in E1X ( $p=0.03$ ) and E10X ( $p=0.03)$ compared with sham. The acrophase was significantly affected $(\mathrm{F}=$ 10.48, $\mathrm{p}=0.01$ ) that approximately $1 \mathrm{hr} 40 \mathrm{~min}$ earlier in E1X $(\mathrm{p}=0.03)$ and $2 \mathrm{hr} 20 \mathrm{~min}$ earlier in E10X $(\mathrm{p}=0.02)$ than in sham (Figure 3, Table 2).

\section{Clock}

Clock expression showed a statistically significant daily rhythm in sham, E1X, and E10X (Table 2). Clock expression was not significantly different from sham in either E1X or E10X. The mesor, amplitude, and acrophase were not changed by ECS (Figure 3, Table 2).

Per1

Per1 expression showed a statistically significant daily rhythm in sham, E1X, and E10X (Table 2). No significant difference in Per1 expression was observed in E1X and E10X compared with sham. The mesor and amplitude showed no difference in both E1X and E10X. The acrophase was observed approximately $3 \mathrm{hr} 13 \mathrm{~min}$ earlier in E10X than in sham (F=
8.31, $\mathrm{p}<0.01$ ) (Figure 3, Table 2).

Per2

Per2 expression showed a statistically significant daily rhythm in sham but not in E1X or E10X (Table 2). There was no difference in Per 2 expression between sham and E1X, while E10X increased Per2 expression ( $\mathrm{F}=17.31, \mathrm{p}<0.01)$ compared with sham. The mesor was increased in E10X $(\mathrm{F}=4.37, \mathrm{p}=$ 0.03 ), and the amplitude showed no difference compared with sham. The acrophase was observed $11 \mathrm{hr} 28 \mathrm{~min}$ earlier in E10X than in sham $(\mathrm{F}=6.29, \mathrm{p}=0.03)$ (Figure 3, Table 2).

\section{Cry1}

Cry1 expression showed a statistically significant daily rhythm in sham, E1X, and E10X (Table 2). Both E1X and E10X lowered Cry1 expression compared with sham $(\mathrm{F}=8.28, \mathrm{p}=$ $0.02 ; \mathrm{F}=31.13, \mathrm{p}<0.01)$. A group $\times$ time interaction was observed between sham and $\mathrm{E} 10 \mathrm{X}(\mathrm{F}=9.61, \mathrm{p}<0.01)$. The mesor was significantly affected $(\mathrm{F}=18.76, \mathrm{p}<0.01)$ that decreased in $\mathrm{E} 1 \mathrm{X}(\mathrm{p}=0.03)$ and E10X $(\mathrm{p}<0.01)$. The amplitude was also affected $(\mathrm{F}=11.49, \mathrm{p}=0.01)$ that decreased in $\mathrm{E} 1 \mathrm{X}(\mathrm{p}=0.02)$ and E10X ( $<<0.01)$. The acrophase occurred approximately $3 \mathrm{hr}$ 50 min later in E10X than in sham $(\mathrm{F}=16.63, \mathrm{p}<0.01)$ (Figure 3, Table 2).

Cry2

Cry2 expression showed a statistically significant daily rhythm in sham, E1X, and E10X (Table 2). E10X decreased Cry2 expression compared with sham $(\mathrm{F}=31.44, \mathrm{p}<0.01)$. The mesor was decreased in E10X $(\mathrm{F}=11.37, \mathrm{p}<0.01)$ compared with sham. The acrophase was significantly changed $(\mathrm{F}=4.06$, $\mathrm{p}=0.03$ ) which occurred approximately $4 \mathrm{hr} 25 \mathrm{~min}$ earlier in E1X ( $p=0.03)$ and $3 \mathrm{hr} 35$ min earlier in E10X $(\mathrm{p}=0.03)$ than in sham (Figure 3, Table 2).

\section{DISCUSSION}

We have demonstrated that ECS alters the expression and daily oscillation of circadian genes in the rat frontal cortex. The ECS-induced changes were more remarkable after repeated treatments than after single treatment suggesting the enhanced effects with the increasing number of ECS. Reduced mRNA expression of Roro, Bmal1, Clock, Per1, and Cry1, and earlier acrophase of Rev-erb $\alpha$, Bmal1, Per1, Per2, and Cry2 suggested the phase advance accompanied with attenuated transcription after repeated ECS treatments.

Circadian gene expression is regulated by integrated feedback loops. ${ }^{22}$ Bmal1 and Clock dimerize and activate transcription of Per1, Per2, Cry1, and Cry2 through binding to the E-box on their promoter regions. ${ }^{41,42} \mathrm{Rev}$-erb $\alpha$ suppresses 


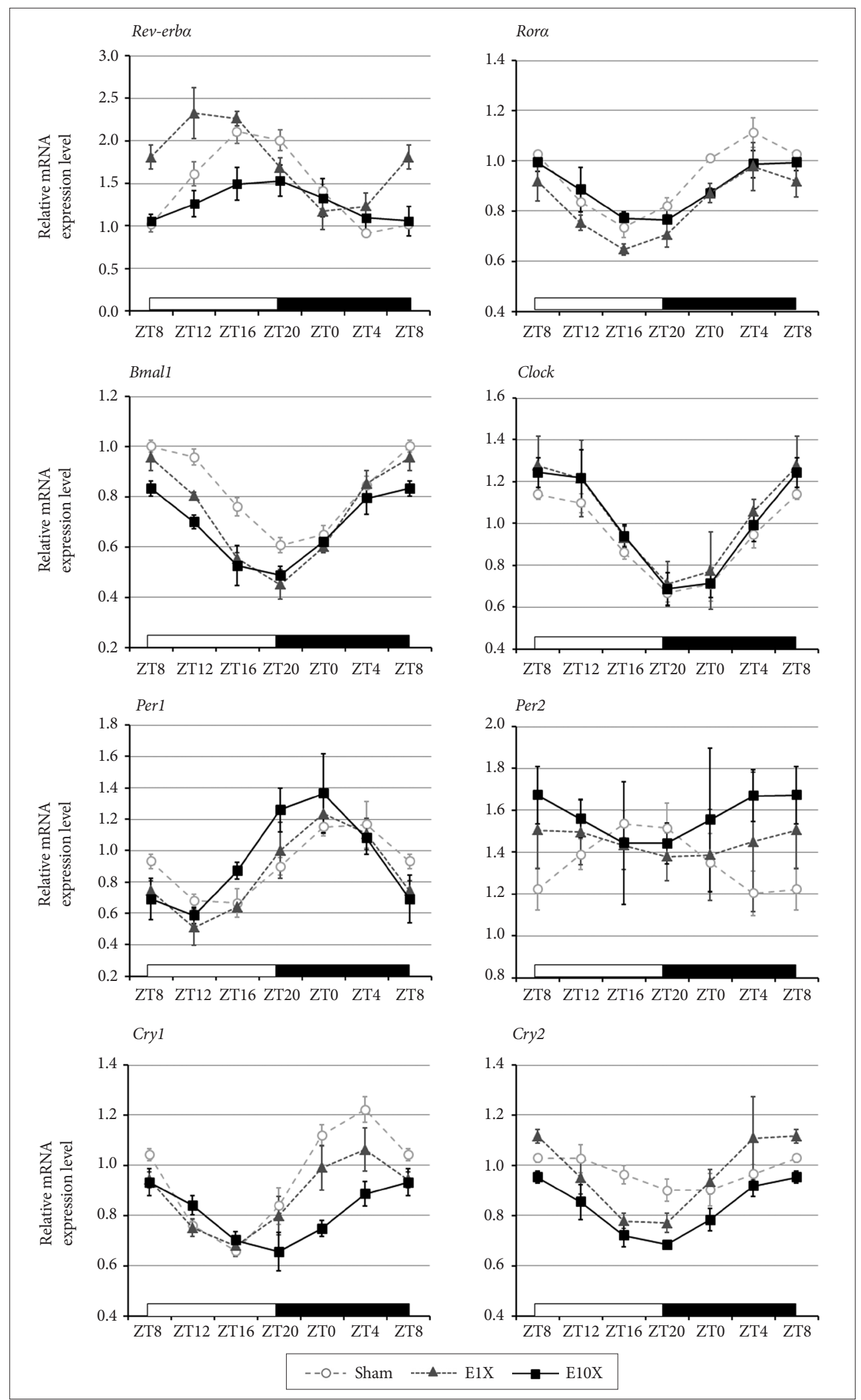

Figure 3. Daily expression pattern of circadian genes in the frontal cortex after ECS treatment. The relative expression of circadian genes in the frontal cortex was analyzed by quantitative real-time PCR. ZT indicates zeitgeber time. The relative expression of each gene was compared with sham control of ZT8 and normalized to $\beta$-actin expression. Data represent means $\pm S E(N=6-9)$. The open bars indicate the lights-on phase, and the dark bars indicate lights off. 


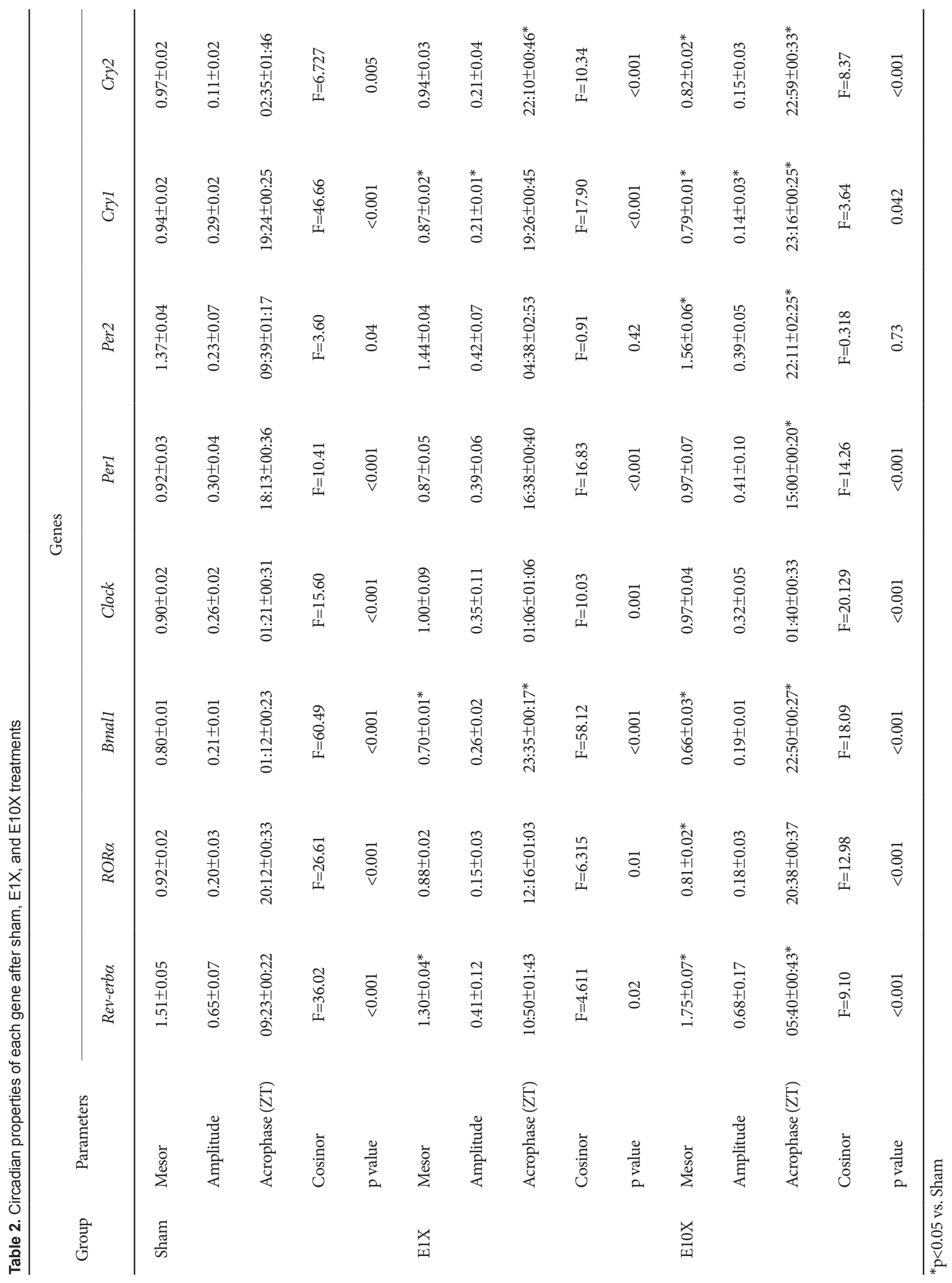


Bmal1 expression via the RORE motif on its promoter region. ${ }^{43}$ Rora activates Bmal1 transcription by competing with Reverba to bind to the RORE on the Bmall promoter. ${ }^{44}$ Therefore, increased Rev-erba along with reduced Rora could result in the reduced Bmall which could relate to the decreased transcription of Per1, Cry1, and Cry 2 after E10X treatment. However, the transcription of these genes are regulated by various mechanisms other than circadian genes themselves, which requires further investigations.

Another possible regulatory mechanism could relate to immediate early gene, Egr1. We have reported that repeated ECS treatments induced prolonged down-regulation of Egr1 expression in the rat frontal cortex. ${ }^{28,30}$ Egr1 was reported to induce the expression of Ror $\alpha$, Bmal1, and Per1, and to reduce that of Rev-erb $\alpha$, Rev-erb $\beta$ and Per2. ${ }^{45}$ E10X-induced decrease in the expression of Rora, Bmal1, and Per1 and increased Rev-erb $\alpha$ expression might relate to the reduced Egr1 level.

All the examined genes showed statistically significant daily oscillation in the frontal cortex of the sham-treated control rats. The present findings support the many previous reports that have demonstrated the diurnal rhythm of clock genes in the frontal cortex. ${ }^{19,46,47}$ Mesor of Rev-erb $\alpha$ was increased, and that of Roro, Bmal1, and Cry1 was reduced in response to E10X. Amplitude was not affected by ECS treatments. Among the examined eight genes, five genes, including Rev-erb $\alpha$, Bmal1, Per1, Per2, and Cry2, showed earlier acrophase after E10X.

Our findings showing the phase advance in the expression of several circadian genes could be compatible with the effects of ECT and other antidepressants on circadian rhythm. The patients with depressive disorders who reached clinical remission after repeated ECT showed the advanced acrophase of the circadian rhythm. ${ }^{48}$ Antidepressants, including agomelatine and trazodone, induce a phase advance. ${ }^{49,50}$ Nonpharmacological treatment modalities for depressive disorder, such as sleep deprivation and light therapy, induce phase advance. ${ }^{51,52}$ Antidepressants and mood stabilizers could reset abnormal clock genes in mood disorders in order to restore and stabilize circadian rhythm. ${ }^{11}$ ECS-induced changes in circadian genes might contribute to the correction of mood instability.

The protein level showed similar pattern of changes compared with mRNA level after ECS except Cry2. mRNA level of Cry2 was decreased, whereas protein level was increased by E10X. Protein degradation through phoshporylation and ubiqutination is the strong contributing factor to the setting of circadian proteins level. ${ }^{23,53}$ Phosphorylation of Cry2 at Ser $553 / 557$ followed by ubiquitination leads to the proteasomal degradation. ${ }^{54,55}$ Further studies will be necessary to understand the regulation of protein level of Cry 2 by repeated ECS treatments.

The present study has several limitations. We performed ex- periments in normal animals, but not in animal models showing disturbances in circadian rhythm. Additional studies using disease animal models could enable us to understand the ECS's effects on circadian genes related to the behaviors and multiple physiological variables. ${ }^{56}$ Rhythm of circadian genes in various brain regions shows not only the phase synchrony across regions but also the region-specific differential patterns. ${ }^{19}$ Studies on multiple brain regions, including SCN, could provide the differential and common effects of ECT on circadian genes across the brain regions. In addition, further studies will be necessary to understand the underlying molecular mechanisms inducing the changes in circadian genes by ECS treatemnts.

In conclusion, the present study shows that ECS, more prominently with repeated treatments, affects the expression and daily oscillation of circadian genes in the rat frontal cortex. Although each gene did not change in a uniform way, reduced transcription and phase advance of several genes after repeated ECS treatments were remarkable. ECT-induced changes in circadian genes could relate to the therapeutic effects, which might provide the potential molecular targets for the treatment of mood disorders.

\section{Acknowledgments}

This study was supported by a grant of the Korea Healthcare Technology R\&D Project, Ministry for Health \& Welfare (HI14C0202), Republic of Korea. Current affiliation of HG Park is 'Burke Medical Research Institute, White Plains, NY, USA'

\section{REFERENCES}

1. Boivin DB. Influence of sleep-wake and circadian rhythm disturbances in psychiatric disorders. J Psychiatry Neurosci 2000;25:446-458.

2. Kapczinski F, Frey BN, Vieta E. Sleep and circadian rhythm disturbances in bipolar disorder: an urgent need for objective assessment and systematic follow-up. J Clin Psychiatry 2011;72:724.

3. Landgraf D, McCarthy MJ, Welsh DK. Circadian clock and stress interactions in the molecular biology of psychiatric disorders. Curr Psychiatry Rep 2014;16:483.

4. Partonen T. Clock gene variants in mood and anxiety disorders. J Neural Transm (Vienna) 2012;119:1133-1145.

5. Mansour HA, Talkowski ME, Wood J, Chowdari KV, McClain L, Prasad K, et al. Association study of 21 circadian genes with bipolar I disorder, schizoaffective disorder, and schizophrenia. Bipolar Disord 2009;11:701-710.

6. Milhiet V, Boudebesse C, Bellivier F, Drouot X, Henry C, Leboyer M, et al. Circadian abnormalities as markers of susceptibility in bipolar disorders. Front Biosci (Schol Ed) 2014;6:120-137.

7. Coogan AN, Papachatzaki MM, Clemens C, Baird A, Donev RM, Joosten J, et al. Haloperidol alters circadian clock gene product expression in the mouse brain. World J Biol Psychiatry 2011;12:638-644.

8. Johansson AS, Brask J, Owe-Larsson B, Hetta J, Lundkvist GB. Valproic acid phase shifts the rhythmic expression of Period2::Luciferase. J Biol Rhythms 2011;26:541-551.

9. Kim SH, Yu HS, Park HG, Ahn YM, Kim YS, Lee YH, et al. Egr1 regulates lithium-induced transcription of the Period 2 (PER2) gene. Biochim Biophys Acta 2013;1832:1969-1979.

10. Sprouse J, Braselton J, Reynolds L. Fluoxetine modulates the circadian biological clock via phase advances of suprachiasmatic nucleus neuronal firing. Biol Psychiatry 2006;60:896-899. 
11. Bunney BG, Li JZ, Walsh DM, Stein R, Vawter MP, Cartagena P, et al. Circadian dysregulation of clock genes: clues to rapid treatments in major depressive disorder. Mol Psychiatry 2015;20:48-55.

12. Lewy AJ, Rough JN, Songer JB, Mishra N, Yuhas K, Emens JS. The phase shift hypothesis for the circadian component of winter depression. Dialogues Clin Neurosci 2007;9:291-300.

13. Pail G, Huf W, Pjrek E, Winkler D, Willeit M, Praschak-Rieder N, et al. Bright-light therapy in the treatment of mood disorders. Neuropsychobiology 2011;64:152-162.

14. Wu JC, Kelsoe JR, Schachat C, Bunney BG, DeModena A, Golshan S, et al. Rapid and sustained antidepressant response with sleep deprivation and chronotherapy in bipolar disorder. Biol Psychiatry 2009;66: 298-301.

15. Reppert SM, Weaver DR. Coordination of circadian timing in mammals. Nature 2002;418:935-941.

16. Guilding C, Piggins HD. Challenging the omnipotence of the suprachiasmatic timekeeper: are circadian oscillators present throughout the mammalian brain? Eur J Neurosci 2007;25:3195-3216.

17. Rath MF, Rohde K, Fahrenkrug J, Moller M. Circadian clock components in the rat neocortex: daily dynamics, localization and regulation. Brain Struct Funct 2013;218:551-562.

18. Rath MF, Rovsing L, Moller M. Circadian oscillators in the mouse brain: molecular clock components in the neocortex and cerebellar cortex. Cell Tissue Res 2014;357:743-755.

19. Li JZ, Bunney BG, Meng F, Hagenauer MH, Walsh DM, Vawter MP, et al. Circadian patterns of gene expression in the human brain and disruption in major depressive disorder. Proc Natl Acad Sci U S A 2013;110: 9950-9955.

20. McCarthy MJ, Welsh DK. Cellular circadian clocks in mood disorders. J Biol Rhythms 2012;27:339-352.

21. Christiansen SL, Bouzinova EV, Fahrenkrug J, Wiborg O. Altered Expression Pattern of Clock Genes in a Rat Model of Depression. Int J Neuropsychopharmacol 2016;19. pii:pyw061.

22. Ukai H, Ueda HR. Systems biology of mammalian circadian clocks. Annu Rev Physiol 2010;72:579-603.

23. Gallego M, Virshup DM. Post-translational modifications regulate the ticking of the circadian clock. Nat Rev Mol Cell Biol 2007;8:139-148.

24. Szuba MP, Guze BH, Baxter LR Jr. Electroconvulsive therapy increases circadian amplitude and lowers core body temperature in depressed subjects. Biol Psychiatry 1997;42:1130-1137.

25. Eun B, Kim HJ, Kim SY, Kim TW, Hong ST, Choi KM, et al. Induction of Per1 expression following an experimentally induced epilepsy in the mouse hippocampus. Neurosci Lett 2011;498:110-113.

26. Voleti B, Tanis KQ, Newton SS, Duman RS. Analysis of target genes regulated by chronic electroconvulsive therapy reveals role for Fzd6 in depression. Biol Psychiatry 2012;71:51-58.

27. Jung HY, Kang UG, Ahn YM, Joo YH, Park JB, Kim YS. Induction of tetradecanoyl phorbol acetate-inducible sequence (TIS) genes by electroconvulsive shock in rat brain. Biol Psychiatry 1996;40:503-507.

28. Park HG, Yu HS, Park S, Ahn YM, Kim YS, Kim SH. Repeated treatment with electroconvulsive seizures induces HDAC2 expression and down-regulation of NMDA receptor-related genes through histone deacetylation in the rat frontal cortex. Int J Neuropsychopharmacol 2014; 17:1487-1500.

29. Tsankova NM, Kumar A, Nestler EJ. Histone modifications at gene promoter regions in rat hippocampus after acute and chronic electroconvulsive seizures. J Neurosci 2004;24:5603-5610.

30. Park HG, Kim SH, Kim HS, Ahn YM, Kang UG, Kim YS. Repeated electroconvulsive seizure treatment in rats reduces inducibility of early growth response genes and hyperactivity in response to cocaine administration. Prog Neuropsychopharmacol Biol Psychiatry 2011;35:10141021.

31. Morris ME, Viswanathan N, Kuhlman S, Davis FC, Weitz CJ. A screen for genes induced in the suprachiasmatic nucleus by light. Science 1998; 279:1544-1547.
32. Tanaka M, Iijima N, Amaya F, Tamada Y, Ibata Y. NGFI-A gene expression induced in the rat suprachiasmatic nucleus by photic stimulation: spread into hypothalamic periventricular somatostatin neurons and GABA receptor involvement. Eur J Neurosci 1999;11:3178-3184.

33. Chen CC. Alterations of protein kinase $\mathrm{C}$ isozyme and substrate proteins in mouse brain after electroconvulsive seizures. Brain Res 1994; 648:65-72.

34. Kang UG, Koo YJ, Jeon WJ, Park DB, Juhnn YS, Park JB, et al. Activation of extracellular signal-regulated kinase signaling by chronic electroconvulsive shock in the rat frontal cortex. Psychiatry Res 2006;145: 75-78.

35. Roh MS, Kang UG, Shin SY, Lee YH, Jung HY, Juhnn YS, et al. Biphasic changes in the Ser-9 phosphorylation of glycogen synthase kinase-3beta after electroconvulsive shock in the rat brain. Prog Neuropsychopharmacol Biol Psychiatry 2003;27:1-5.

36. Cotter D, Mackay D, Chana G, Beasley C, Landau S, Everall IP. Reduced neuronal size and glial cell density in area 9 of the dorsolateral prefrontal cortex in subjects with major depressive disorder. Cereb Cortex 2002;12:386-394.

37. Drevets WC, Price JL, Simpson JR Jr, Todd RD, Reich T, Vannier M, et al. Subgenual prefrontal cortex abnormalities in mood disorders. Nature 1997;386:824-827.

38. Cornelissen G. Cosinor-based rhythmometry. Theor Biol Med Model 2014;11:16.

39. Mojon A, Fernandez JR, Hermida RC. Chronolab: an interactive software package for chronobiologic time series analysis written for the Macintosh computer. Chronobiol Int 1992;9:403-412.

40. Refinetti R, Lissen GC, Halberg F. Procedures for numerical analysis of circadian rhythms. Biol Rhythm Res 2007;38:275-325.

41. Gekakis N, Staknis D, Nguyen HB, Davis FC, Wilsbacher LD, King DP, et al. Role of the CLOCK protein in the mammalian circadian mechanism. Science 1998;280:1564-1569.

42. Kume K, Zylka MJ, Sriram S, Shearman LP, Weaver DR, Jin X, et al. mCRY1 and mCRY2 are essential components of the negative limb of the circadian clock feedback loop. Cell 1999;98:193-205.

43. Yin L, Wu N, Lazar MA. Nuclear receptor Rev-erbalpha: a heme receptor that coordinates circadian rhythm and metabolism. Nucl Recept Signal 2010;8:e001.

44. Liu AC, Tran HG, Zhang EE, Priest AA, Welsh DK, Kay SA. Redundant function of REV-ERBalpha and beta and non-essential role for Bmal1 cycling in transcriptional regulation of intracellular circadian rhythms. PLoS Genet 2008;4:e1000023.

45. Tao W, Wu J, Zhang Q, Lai SS, Jiang S, Jiang C, et al. EGR1 regulates hepatic clock gene amplitude by activating Perl transcription. Sci Rep 2015;5:15212.

46. Erburu M, Cajaleon L, Guruceaga E, Venzala E, Munoz-Cobo I, Beltran E, et al. Chronic mild stress and imipramine treatment elicit opposite changes in behavior and in gene expression in the mouse prefrontal cortex. Pharmacol Biochem Behav 2015;135:227-236.

47. Li SX, Liu LJ, Jiang WG, Sun LL, Zhou SJ, Le Foll B, et al. Circadian alteration in neurobiology during protracted opiate withdrawal in rats. J Neurochem 2010;115:353-362.

48. Winkler D, Pjrek E, Lanzenberger R, Baldinger P, Eitel D, Kasper S, et al. Actigraphy in patients with treatment-resistant depression undergoing electroconvulsive therapy. J Psychiatr Res 2014;57:96-100.

49. Krauchi K, Cajochen C, Mori D, Graw P, Wirz-Justice A. Early evening melatonin and S-20098 advance circadian phase and nocturnal regulation of core body temperature. Am J Physiol 1997;272:R1178-R1188.

50. Suzuki H, Yamadera H, Nakamura S, Endo S. Effects of trazodone and imipramine on the biological rhythm: an analysis of sleep EEG and body core temperature. J Nippon Med Sch 2002;69:333-341.

51. Benedetti F, Dallaspezia S, Fulgosi MC, Barbini B, Colombo C, Smeraldi E. Phase advance is an actimetric correlate of antidepressant response to sleep deprivation and light therapy in bipolar depression. Chronobiol Int 2007;24:921-937. 
52. Winkler D, Pjrek E, Praschak-Rieder N, Willeit M, Pezawas L, Konstantinidis A, et al. Actigraphy in patients with seasonal affective disorder and healthy control subjects treated with light therapy. Biol Psychiatry 2005;58:331-336.

53. Stojkovic K, Wing SS, Cermakian N. A central role for ubiquitination within a circadian clock protein modification code. Front Mol Neurosci 2014;7:69.

54. Harada Y, Sakai M, Kurabayashi N, Hirota T, Fukada Y. Ser-557-phos- phorylated $\mathrm{mCRY} 2$ is degraded upon synergistic phosphorylation by glycogen synthase kinase-3 beta. J Biol Chem 2005;280:31714-31721.

55. Kurabayashi N, Hirota T, Sakai M, Sanada K, Fukada Y. DYRK1A and glycogen synthase kinase 3beta, a dual-kinase mechanism directing proteasomal degradation of CRY2 for circadian timekeeping. Mol Cell Biol 2010;30:1757-1768.

56. Landgraf D, McCarthy MJ, Welsh DK. The role of the circadian clock in animal models of mood disorders. Behav Neurosci 2014;128:344-359. 